https://helda.helsinki.fi

\title{
Lactobacillus alimentarius : a specific spoilage organism in marinated herring
}

\section{Lyhs, Ulrike}

Elsevier

2001

International journal of food microbiology . 2001. 64(3 ): 355-360.

http://hdl.handle.net/1975/531

http://dx.doi.org/10.1016/S0168-1605(00)00486-4

Downloaded from Helda, University of Helsinki institutional repository.

This is an electronic reprint of the original article.

This reprint may differ from the original in pagination and typographic detail.

Please cite the original version. 
1 Lactobacillus alimentarius - a specific spoilage organism in marinated herring

2

3 Ulrike Lyhs $*^{1}$, Hannu Korkeala ${ }^{1}$, Peter Vandamme ${ }^{2}$ and Johanna Björkroth ${ }^{1}$

4

$5 \quad{ }^{1}$ Department of Food and Environmental Hygiene, Faculty of Veterinary Medicine,

$6 \quad$ University of Helsinki, Finland

$7 \quad$ 2Laboratory of Microbiology, University of Gent, Belgium

8

9

10

*Corresponding author: Ulrike Lyhs

Mailing address:

Department of Food and Environmental Hygiene 


\section{Abstract}

Spoilage characterised by bulging of lids and gas formation affected various product lots of different marinated herring types. Microbiological analyses resulted in growth on MRS and Rogosa SL agar. Altogether, 206 randomly selected colonies from two unspoiled and ten spoiled samples were characterised using phenotypical key tests and a 16+23S rRNA gene-based RFLP identification database. $L$. alimentarius was found to be the specific spoilage organism in all samples. All isolates obtained from the different product types were of the same clonal type. The slight rise in $\mathrm{pH}$ value together with marked gas production suggested a rare lactic acid bacteria spoilage type called 'protein swell'. L. alimentarius has not been previously associated with herring spoilage.

Key words: Herring; Spoilage; Lactobacillus alimentarius

5




\section{Introduction}

In marinated herring products, the raw or cooked herring is preserved in vinegar and salt to inhibit spoilage caused by salt-and acid-sensitive putrefactive bacteria. Bacterial growth and spoilage may still occur due to the growth of non-putrefactive organisms which can survive in acidic and high-salt environments. The growth of acetic acid-tolerant lactic acid bacteria (LAB) may form this spoilage flora in marinated herring. As the first sign of spoilage after some storage weeks, gas formation may occur due to the growth of these organisms (Blood, 1975).

Lactobacillus spp. have been identified as the specific spoilage organisms in marinated herring (Meyer, 1956b, 1962c; Kreuzer, 1957; Lerche, 1960; Reuter, 1965; Erichsen, 1967; Sharpe and Pettipher, 1983). In different kinds of spoiled herring types heterofermentative Lactobacillus spp. as L. brevis, L. buchneri and $L$. fermentum have been predominating (Meyer, 1956b; Kreuzer, 1957; Lerche, 1960; Meyer, 1962c; Reuter, 1965; Erichsen, 1967; Sharpe and Pettipher, 1983). Moreover, L. plantarum and L. delbruckii subsp. lactis (L. leichmannii), possessing homofermentative glucose metabolism, have been detected in some spoilage cases (Lerche, 1960; Meyer, 1962c; Sharpe and Pettipher, 1983). In unspoiled marinades, $L$. buchneri and L. delbruckii subsp. lactis have been identified (Reuter, 1965).

During this study, spoilage of marinated herring products was assessed. Clear bulging of lids and gas formation indicated spoilage after a few storage weeks of various marinated herring types from different lots produced by one company. At the time of the study, seven months of the expected shelf-lives were still remaining. The aim of this work was to characterise and identify the main spoilage LAB causing the gas production and spoilage. The species identification in the previous studies had been performed by means of phenotypical testing. Since these tests have been found 
1 insufficient in the identification of many LAB (Björkroth et al., 1998, 2000; Lyhs et al., 1998) a 16+23 rRNA gene RFLP (ribotyping) database was used. This has been shown to be an excellent tool for LAB species identification (Björkroth and Korkeala, 1997; Lyhs et al., 1999).

\section{Material and methods}

\subsection{Product description and sampling}

A total of twelve glass jars containing marinated herring were sampled; ten of these showed clear bulging of lids and gas formation indicating spoilage, and two jars had a normal appearance. All jars contained herring cut into pieces, water, sugar (saccharose), salt $(\mathrm{NaCl})$, onions, vinegar, spices and sodium benzoic acid as a preservative. The two normal (nos. 1 and 2) and six of the spoiled (nos. 3 to 8) samples contained only the basic ingredients described above. Three spoiled samples (nos. 9 to 11) also contained garlic and one spoiled sample (no. 12) additional onion to the base marinade. According to the manufacturer, the salt concentration of each sample was $3 \%$. The recommended storage temperature was $4^{\circ} \mathrm{C}$ to $8^{\circ} \mathrm{C}$.

\subsection{Microbiological analyses and selection of the strains for further characterisation}

A $10 \mathrm{~g}$ portion of herring in marinade was aseptically weighed into $90 \mathrm{ml}$ of $0.9 \% \mathrm{NaCl}(\mathrm{w} / \mathrm{v})$ and $0.1 \%(\mathrm{w} / \mathrm{v})$ peptone water in a sterile plastic bag, and then blended in a Stomacher 400 Lab Blender (Seward Medical, London, UK) for 30 seconds. Ten-fold serial dilutions were used for microbiological analyses. LAB were determined by the method of the Nordic Committee on Food Analysis (1991) using MRS agar (Oxoid, Basingstoke, UK). Rogosa SL agar (Orion Diagnostica, Espoo, 
1 Finland) was cultured parallel to MRS agar (Oxoid). All plates were incubated in an anaerobic jar with a $\mathrm{H}_{2}+\mathrm{CO}_{2}$ generating kit (Oxoid) at $25^{\circ} \mathrm{C}$ for 5 days. The $\mathrm{pH}$ was determined from the first dilution by a WTW-530 Digital-pH-meter (Wissenschaftliche-Technische Werkstätten, Weilheim, Germany).

A total of 206 colonies were cultured pure. All six isolates growing on MRS agar from the unspoiled samples were included. With respect to all spoiled samples, half of the isolates analysed originated from MRS agar, and the other half from Rogosa SL agar. All 206 isolates were subjected to basic phenotyping and HindIII REA analyses. The isolates were maintained in MRS broth (Difco, Detroit, Michigan, USA) at $-70^{\circ} \mathrm{C}$ and cultured using MRS broth (Difco) or MRS agar (Oxoid).

\subsection{Phenotypic characterisation}

All isolates were Gram-stained and catalase-tested. Production of gas from glucose was studied using the method of Schillinger and Lücke (1987).

2.4. Isolation of DNA, restriction endonuclease analysis (REA) and determination of 16+23S rRNA gene restriction patterns (ribotyping)

The similarity between isolates was initially checked using HindIII REA. Two isolates from each jar of herring were further subjected to ribotyping. HindIII was chosen because it has been found to provide species-specific patterns for spoilage LAB (Björkroth and Korkeala, 1996; Björkroth et al., 1998, 2000).

DNA was isolated according to the guanidium thiocyanate method of Pitcher et al. (1989), modified by Björkroth and Korkeala (1996) with combined mutanolysin (Sigma Chemical Company, St. Louis, MO, USA) and lysozyme (Sigma) treatment. Restriction endonuclease digestion of $6 \mu \mathrm{g}$ of DNA was done according to 
manufacturer instructions with HindIII enzyme (New England Biolabs, Beverly, MA, USA). REA, southern transfer, hybridisation and the cDNA probe for rRNA gene restriction patterns (ribotypes) were prepared as described by Björkroth and Korkeala (1996).

\subsection{Ribotyping data management}

The membranes were scanned with a Hewlett-Packard ScanJet 4c/T tabletop scanner (Boise, Idaho, USA). Numerical analysis of the ribopatterns was performed using the Gelcompar II software package (Applied Maths, Kortrijk, Belgium). A 1-\% position tolerance was allowed for the bands. The similarity between all pairs was expressed by Dice coefficient correlation, and the unweighted pair-group method with arithmetic averages (UPGMA) was used for the construction of the dendrogram. The ribopatterns were compared with the corresponding patterns in the LAB database at the Department of Food and Environmental Hygiene, University of Helsinki, Finland, which comprises patterns for all relevant spoilage LAB in the genera of Carnobacterium, Lactobacillus, Leuconostoc, Enterococcus and Weissella (Björkroth and Korkeala, 1996, 1997; Björkroth et al., 1998, 2000; Lyhs et al., 1999). For the dendrogram, heterofermentative reference strains and the $L$. alimentarius type strain were included (Fig. 2).

\section{Results}

Visual examination of the herring from the bulging jars showed soft herring flesh, cloudy marinade and strong gas production. These changes were not seen in the unspoiled samples. $\mathrm{pH}$ values in the spoiled samples ranged from $\mathrm{pH} 3.7$ to 3.9, as compared with a $\mathrm{pH}$ of 3.6 to 3.7 in the samples showing no gas formation. LAB 
1 counts in the unspoiled samples were clearly lower than in the spoiled samples (Table

2 1). Counts in all herring samples were very similar on parallel MRS and Rogosa SL

3 media, suggesting Lactobacillus spp. growth. All isolates were Gram-positive,

4 catalase-negative, short, thick or long, filamentous rods. A total 139 of the 206

5 isolates showed gas production in the media used (Schillinger and Lücke, 1987).

All 206 LAB isolates originating from different jars of different marinated

\section{Discussion}

L. alimentarius has not been previously reported as a predominant spoilage organism in gaseous spoilage of herring. Reuter (1983) has detected L. alimentarius in marinated fish products, meat products (fermented sausages, sliced prepackaged sausages) and sour dough. Usually, in the case of LAB spoilage, the $\mathrm{pH}$ of the product decreases due to lactic acid formation. However, in our study, a slight $\mathrm{pH}$ rise was observed. Meyer (1956a) reported this type of spoilage in canned semi-preserved fish and named it 'protein swell'. He distinguished it from 'carbohydrate swell', where increased acidity and $\mathrm{CO}_{2}$ formation result from heterofermentative utilisation of glucose. In contrast to 'protein swell', 'carbohydrate swell' can result in very low pH values. In a case of Lactobacillus fructivorans spoilage in tomato ketchup, $\mathrm{pH}$ values as low as 3.3 to 3.4 were detected (Björkroth and Korkeala, 1997). 
The decrease in acidity related to 'protein swell' has been attributed to production of ammonia by bacterial deamination of amino acids. Later, Meyer (1962b) suggested that the acetic acid provides an acidic environment appropriate for the action of protoelytic enzymes present in fish muscle. The products of proteolysis, i.e. amino acids, provide an energy source for the growth of the acetic acid-tolerant LAB, leading to carbon dioxide production. While LAB activity has been associated only with degradation of oligopeptides and free amino acids (Verplaetse, 1994; Molly et al., 1997), it may also cause formation of biogene amines. However, the product studied here was in such an advanced stage of spoilage that its consumption would be very improbable. To restrict the growth of LAB, Meyer (1956b) recommended for the marinating process a $\mathrm{pH}$ value no higher than 4.0, a salt concentration of the marinade not much under $6 \%$ and a storage temperature as low as possible. 'Protein swell' has also been associated with anchovy-stuffed olives (Harmon et al., 1987). L. plantarum and L. brevis growth have been observed, and enzymes originating from the anchovy were considered to be the reason for initial proteolysis.

If enhanced $\mathrm{CO}_{2}$ production is caused by decarboxylation of amino acids, the LAB having an effect on gas production may possess homofermentative glucose metabolism, similar to L. alimentarius. Facultatively heterofermentative Lactobacillus spp. may produce $\mathrm{CO}_{2}$ while utilising gluconate or citrate. In food containing many substrates, L. alimentarius strains may have utilised substrates leading to $\mathrm{CO}_{2}$ formation without amino acid decarboxylation. Thus, the gaseous spoilage described here might not represent a typical form of 'protein swell'. The nominal change in $\mathrm{pH}$ values between spoiled and unspoiled samples increases this doubt. However, facultative heterofermentative organisms show no gas production in the test determining the glucose utilisation type; yet, 139 of the 206 isolates did show gas 
1 production when tested (Schillinger and Lücke, 1987). These controversial reactions

caused by facultatively heterofermentative Lactobacillus spp. have also been reported earlier. In a study of LAB from a sorghum-based fermented weaning food, Kunene et al. (2000) described 25 strains from the facultative heterofermentative $L$. sakei/curvatus-group as gas producing. They used the same test (Schillinger and Lücke, 1987) for determination of glucose fermentation type as in the present study. Because this medium contains no gluconate or citrate, the reason for gas production is unclear. However, false results from glucose fermentation type determination will lead to false species identification if only phenotypic characteristics are used.

In our study, all isolates originating from various lots of different marinated herring types were of the same clonal type. This suggests contamination of the processing facilities with an organism thriving at the processing environment and possessing strong spoilage potential. In fish originating from temperate waters, lactobacilli can be found among the dominant psychrotrophic Gram-negative bacteria in only very low numbers (Huss, 1995). Krüger (1973) suggested that LAB contaminate herring products during the processing as a secondary contamination. However, since salt concentrations lower than 6\% are commonly used in herring today, it is difficult to prevent the contaminating Lactobacillus spp. from growing.

\section{Conclusion}

A single L. alimentarius clone was found to be the specific spoilage organism in different marinated herring types. Since the gas production test yielded misleading results, ribotyping was very useful for the identification of the specific spoilage organisms. In order to prevent gaseous spoilage of herring with LAB, good manufacturing hygiene should be maintained. 


\section{References}

Björkroth, J., Korkeala, H., 1996. rRNA gene restriction patterns as a characterization tool for Lactobacillus sakei strains producing ropy slime. Int. J. Food Microbiol. 30, 293-302.

Björkroth, J., Korkeala, H., 1997. Characterization of Lactobacillus fructivorans spoilage in ketchup. J. Food Prot. 60, 505-509.

Björkroth, J., Vandamme P., Korkeala, H., 1998. Identification and characterisation of Leuconostoc carnosum, associaoted with production and spoilage of vacuumpackaged, sliced, cooked ham. Appl. Environm. Bacteriol. 64, 3313-3319.

Björkroth, J., Geisen, R., Schillinger, U., Weiss, N., De Vos, P., Holzapfel, W.H., Korkeala, H., Vandamme, P., 2000. Characterization of Leuconostoc gasicomitatum sp. nov. associated with spoiled raw tomato-marinated broiler meat strips packaged under modified atmosphere conditions. Appl. Environm. Microbiol. (in press).

Blood, R.M., 1975. Lactic acid bacteria in beverages and food. Proceedings of the $4^{\text {th }}$ Long Ashton Symposium 1973, Academic Press, London, pp. 195.

Erichsen, I., 1967. The microflora of semi-preserved fish products III. Principal groups of bacteria occurring in tibits. Antonie van Leeuwenhoek 33, 107-112. Harmon, S.M., Kautter, D.A., McKee, C., 1987. Spoilage of anchovy-stuffed olives by heterofermentative lactobacilli. J. Food Safety 8, 205-210. 
1 Huss, H.H., 1995. Quality and quality changes in fresh fish. In: Huss, H.H. (Ed.),

$2 \quad$ FAO Fish Tech. Pap. 348, FAO Rome, Italy, pp. 51.

Kreuzer, R., 1957. Untersuchungen über den biologisch bedingten Verderb von

5 Fischwaren und seine Verhinderung. I. Kaltmarinaden-Organismem und Milieu. $6 \quad$ Arch. Fisch Wiss. 8, $104-139$.

7

Kunene, N.F., Geornaras, I., von Holy, A., Hastings, J.W., 2000. Characterization and determination of origin of lactic acid bacteria from a sorghum-based fermented weaning food by analysis of soluble proteins and amplified fragment length polymorphism fingerprinting. Appl. Environm. Microbiol. 66, 1084-1092.

Lerche, M., 1960. Bombage-Ursache in Fischpräserven. Berl. Münch. Tierärztl. Wochenschr. 75, 12-14.

Lyhs, U., Björkroth, J., Hyytiä E., Korkeala, H., 1998. The spoilage flora of vacuumpackaged, sodium nitrite or potassium nitrate treated, cold-smoked rainbow trout stored at $4^{\circ} \mathrm{C}$ or $8^{\circ} \mathrm{C}$. Int. J. Food Microbiol. 45, 135-142.

Lyhs, U., Björkroth, J., Korkeala, H., 1999. Characterisation of lactic acid bacteria from spoiled, vacuum-packaged, cold-smoked rainbow trout using ribotyping. Int. J. Food Microbiol. 52, 77-84. 
1 Meyer, V., 1956a. Die Bestimmung der Bombage-Arten bei Fischkonserven.

2 Fischwirtsch. 8, 212-224.

4 Meyer, V., 1956b. Probleme des Verderbens von Fischkonserven in Dosen. II.

5 Aminosäuredecarboxylase durch Organismen der Betabacterium-Buchneri-Gruppe als

6 Ursache bombierter Marinaden. Veröff. Inst. Meeresforsch. Bremerhaven 4, 1-16.

7

Meyer, V., 1962c. Über Milchsäurebakterien in Fischmarinaden. Zentrbl. Bakt. Parastikde. 1, Orig. 184, 296-302.

Molly, K., Demeyer, D.I., Johansson, G., Raemaekers, M., Ghistelnick, M., I. Greenen, 1997. The importance of meat enzymes in ripening and flavour generation in dry fermented sausages: first results of a European project. Food Chem. 59, 539545.

Nordic Committee on Food Analysis, 1991. Lactic acid bacteria. Determination in meat and meat products. NCFA method no. 140, Espoo, Finland.

Pitcher, D.G., Saunders, N.A., Owen, R.J., 1989. Rapid extraction of bacteria genomic DNA with guanidium thiocynate. Lett. Appl. Microbiol. 8, 151-156. 
1 Reuter, G., 1965. Das Vorkommen von Laktobazillen in Lebensmitteln und ihr

2 Verhalten im menschlichen Intestinaltrakt. Zentrbl. Bakt. Parastikde. 1, Orig. 197, 3468.

4

5 Reuter, G., 1983. Lactobacillus alimentarius sp. nov., nom rev. and Lactobacillus

$6 \quad$ farciminis sp. nov., nom. rev. System. Appl. Microbiol. 4, 277-279.

7

8 Schillinger, U., Lücke, K.F., 1987. Identification of lactobacilli from meat and meat 9 products. Food Microbiol. 4, 199-208.

10

Sharpe, M.E., Pettipher, G.L., 1983. Food spoilage by lactic acid bacteria. Econom. Microbiol. 8, 199-223.

Verplaetse, A., 1994. Influence of raw meat properties and processing technology on aroma quality of raw fermented meat products. In: Proceedings of the $40^{\text {th }}$ International Congress on Meat and Technology. The Hague, The Nertherlands, pp. 45-65.

(1)

(1)

21


1 Table 1

2 Growth on MRS and Rogosa SL agar and $\mathrm{pH}$ values analysed from marinated

3 herring jars of normal appearance and those with bulging lids indicating spoilage

\begin{tabular}{|c|c|c|c|}
\hline \multirow[t]{2}{*}{ Sample no. } & \multicolumn{2}{|c|}{ Bacterial counts (cfu/g) } & \multirow[t]{2}{*}{$\mathrm{pH}$} \\
\hline & MRS agar & Rogosa SL agar & \\
\hline $1^{\mathrm{a}}$ & $3 \times 10^{2}$ & $<100$ & 3.6 \\
\hline $2^{a}$ & $<100$ & $<100$ & 3.7 \\
\hline 3 & $1.2 \times 10^{7}$ & $6 \times 10^{6}$ & 3.7 \\
\hline 4 & $2.5 \times 10^{6}$ & $1.6 \times 10^{6}$ & 3.8 \\
\hline 5 & $1.7 \times 10^{7}$ & $1.3 \times 10^{7}$ & 3.7 \\
\hline 6 & $8 \times 10^{6}$ & $6.1 \times 10^{6}$ & 3.8 \\
\hline 7 & $1.9 \times 10^{6}$ & $2.8 \times 10^{6}$ & 3.9 \\
\hline 8 & $5.6 \times 10^{6}$ & $3.9 \times 10^{6}$ & 3.7 \\
\hline 9 & $2.5 \times 10^{7}$ & $1.1 \times 10^{7}$ & 3.7 \\
\hline 10 & $1.3 \times 10^{7}$ & $1.2 \times 10^{7}$ & 3.7 \\
\hline 11 & $9.2 \times 10^{6}$ & $8.9 \times 10^{6}$ & 3.7 \\
\hline 12 & $1.7 \times 10^{6}$ & $1.6 \times 10^{6}$ & 3.8 \\
\hline
\end{tabular}

$4 \quad{ }^{\mathrm{a}}$ Samples of normal appearance.

5 
1 Legends to the figures:

2

3 Fig. 1. Restriction endonuclease patterns obtained in the HindIII restriction

4 endonuclease analysis of the herring spoilage isolates. Lanes $1 \mathrm{a}-2 \mathrm{~b}$, strains isolated

5 from the two unspoiled samples; lanes 3a - 10a, strains isolated from the ten spoiled

6 samples. Lambda DNA cleaved by HindIII was used as a molecular weight marker.

7

8

9

kb 1a 1b 2a MW 2b 3a 3b 4a 4b 5a MW 5b 6a 6b 7a 7b 8a MW 8b 9a 10a

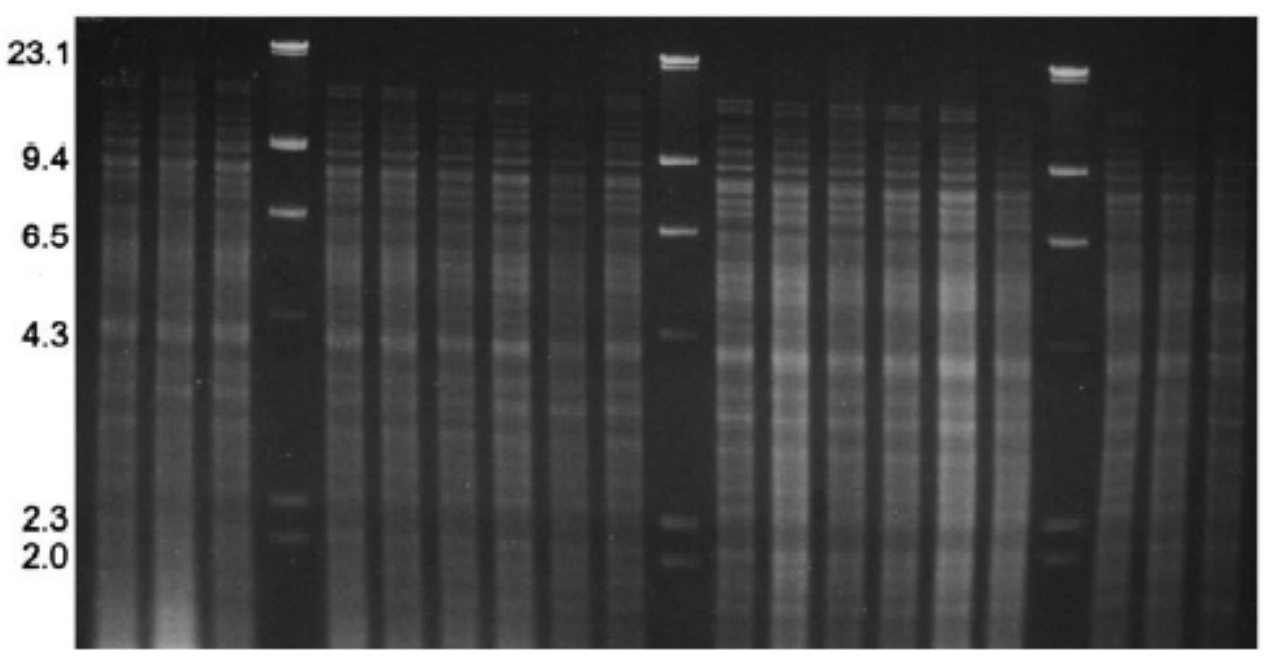

10 
1 Fig. 2. Dendrogram and schematic banding patterns based on HindIII ribopatterns.

2 Nos. 179, 192 and 200 represent herring spoilage strains.

3

4

5

6
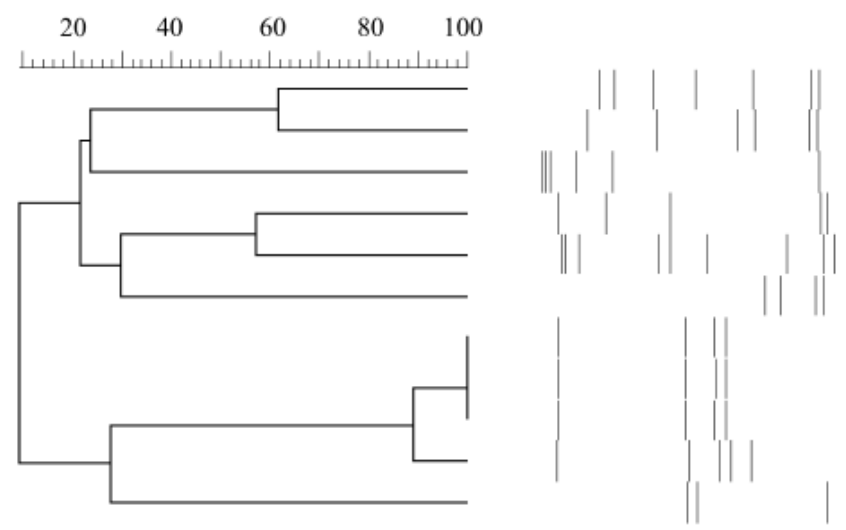

Lactobacillus hilgardii

Lactobacillus collinoides

ATCC $8290^{\mathrm{T}}$

Lactobacillus plantarum

$\operatorname{ATCC} 27612^{\top}$

Lactobacillus brevis

ATCC $14917^{\top}$

Lactobacillus buchneri

ATCC $14869^{7}$

ATCC $4005^{i}$

Lactobacillus fructivorans

ATCC $8288^{7}$

200

192

179

Lactobacillus alimentarius

DSM $20249^{7}$

Lactobacillus fermentum

CCUG $30138^{\top}$

8

9 